\title{
Vzdělání u osob se zkušeností s náhradní formou péče v dětství ${ }^{1}$
}

\author{
Lucie Myškováa, Irena Smetáčkováa, Hana Novotnáa , Jakub \\ Onder ${ }^{a}$, Hana Kuželováb, Radek Ptáček ${ }^{b}$ \\ ${ }^{a}$ Univerzita Karlova v Praze, Pedagogická fakulta, Katedra psychologie, \\ ${ }^{\mathrm{b}}$ Univerzita Karlova v Praze, 1. lékařská fakulta, Psychiatrická klinika
}

Redakci zasláno 17. 6. 2014 / upravená verze obdržena 1.11. 2014 / k uveřejnění přijato 14. 11.2014

\begin{abstract}
Abstrakt: Cílem sdělení je představení dílčích výsledků výzkumu, který se zabýval vlivem dlouhodobého pobytu osob v náhradních formách péče (tj. v ústavní výchově a v náhradních rodinách) na různé oblasti života v dospělosti. Sledovanou oblastí v prezentované části studie byla dosavadní vzdělávací dráha respondentů. $V$ první části jsou přibližzeny typy těchto forem péče v ČR $\mathrm{s}$ bližším představením ústavní výchovy. Druhá část př́íspěvku předkládá dílčí část studie, kde byla pomocí anamnestického dotazníku a baterie psychologických testů porovnávána výzkumná skupina dospělých osob se zkušeností s náhradní péčí v dětství $(\mathrm{n}=128)$ a kontrolní skupina osob vyrůstajících $\mathrm{v}$ původních rodinách $(\mathrm{n}=103)$. Třetí část příspěvku je věnována výsledkům týkajícím se nejvyššího dosaženého vzdělání, cesty k němu a dotýká se také pohledu na dosažené vzdělání přes rozdíly v osobnostních rysech. Ukázalo se, že lidé, kteř́ strávili celé či část svého dětství v náhradních formách péče, dosahují nižšího vzdělání, mají nižší vzdělanostní aspirace, ve své školní trajektorii se potýkají s většími potížemi a od okolí získávají menší podporu v učení. $Z$ uvedeného vyplývají doporučení ve vztahu k vzdělávacímu procesu dětí umístěných v náhradních formách péče.
\end{abstract}

Klíčová slova: školní úspěšnost, vzdělání, náhradní péče, dětský domov

Děti, o které se jejich rodiče neumí, nechtějí nebo nemohou starat, mohou být umístěny v náhradních formách péče. V České republice mohou být umístěny do náhradní rodinné péče (např osvojení či pěstounská péče) nebo do náhradní výchovné péče (např. dětský domov, dětský domov se školou). ${ }^{2} \mathrm{~V}$ posledních letech se upřednostňuje umistování dětí do náhradní rodinné péče,

Výzkum byl podpořen Nadací J\&T.

2 Platnou legislativou pro zařízení pro výkon ústavní a ochranné výchovy je zejm. školský zákon a zákon č. 109/2002 Sb., ve znění pozdějších předpisů. Vedle školství se ale o téma ohroženého dítěte zajímají také další resorty, ve vztahu k náhradní rodinné péči je potřeba zmínit především resort MPSV, který v uplynulých letech kladl důraz na úpravu pěstounské péče. 
zatímco v minulosti naopak koncepčně i početně dominovalo zařazování dětí do ústavní výchovy (Vocilka, 1999).

Náhradní rodinná péče je $\mathrm{v}$ České republice realizována svěřením dítěte do péče fyzické osoby soudem, a to ve formě pěstounské péče nebo svěřením do péče jiné fyzické osoby než rodiče, případně může být dítěti ustanoven poručník či opatrovník pro ochranu zájmů a zastupování dítěte. Do roku 2013 byla formou náhradní rodinné péče také adopce (osvojení), což se s platností nového občanského zákoníku změnilo.

Náhradní výchovná péče je zajištována institucionálně. Zařízení pro výkon ústavní a ochranné výchovy se liší cílovou skupinou, velikostí, systémem vnitřní organizace (věkově homogenní skupiny se stř́idajícími se vychovateli versus „rodinné jednotky“ s heterogenním složením a přiřazenými vychovateli) a místem realizace školní docházky. Dětské domovy jsou školská zařrizení, kde mohou být umístěny děti od 3 let zpravidla do 18 let věku dítěte. Děti navštěvují běžnou školu, která není součástí zařízení. $V$ tom se liší dětské domovy se školou, to jsou zařízení, do kterých jsou umistovány děti zpravidla do dokončení povinné školní docházky. Škola je součástí zařízení a navštěvují ji pouze děti tam umístěné. Zařízení kladou větší důraz na režimové prvky. Děti z nich většinou přechází do výchovných ústavů, což jsou školská zařízení pro výkon ústavní a ochranné výchovy pro mládež, před ukončením povinné školní docházky se do tohoto typu zařízení umist'ují děti výjimečně, a to zpravidla tehdy, mají-li uloženou ochrannou výchovu. ${ }^{3}$

Statistiky MŠMT a MPSV uvádí, že na konci roku 2012 v zařízeních ústavní a ochranné výchovy (vyjma diagnostických ústavů) pobývalo necelých 7000 dětí a v náhradní rodinné péči ${ }^{4}$ přes 15000 dětí (zdroj MPSV), z toho více než 7500 dětí bylo v pěstounské péči. Vývoj umístění dětí v ústavní výchově v posledních deseti letech ukazuje tabulka 1.

3 Ústavní výchovu soud nařizuje především jako nahrazení nedostatečného nebo dokonce chybějícího výchovného prostředí, které negativně ovlivňuje vývoj dítěte (což se může projevit i závadovým chováním dítěte). Ochranná výchova může být uložena po spáchání činu jinak trestného dítětem nebo mladistvým a má pozitivně ovlivnit jeho vývoj a zároveň chránit společnost. Oba typy výchovy mohou být vykonány ve stejném školském zařízení, jsou nařízeny nebo uloženy soudem a jenom soudem (nebo dovršením zletilosti) mohou být opět zrušeny.

4 Náhradní rodinnou péčí se zde rozumí pěstounská péče, péče poručnická či péče jiné fyzické osoby než rodiče. 
Tabulka 1

Počet umístěných dětí ve vybraných zařizeních pro výkon ústavní a ochranné výchovy

\begin{tabular}{lccc}
\hline & Rok 2003/2004 & Rok 2008/2009 & Rok 2012/2013 \\
\hline Dětský domov & 4657 & 4739 & 4442 \\
Dětský domov se školou & 555 & 742 & 713 \\
Výchovný ústav & 1544 & 1446 & 1269 \\
\hline Cekem & 6756 & 6927 & 6424 \\
\hline
\end{tabular}

Pozn. Zdroj: MŠMT.

Vzhledem $\mathrm{k}$ věkovému rozpětí respondentů je zřejmé, že někteří byli umístěni v náhradních formách výchovy a péče ještě před platností zákona o výkonu ústavní a ochranné výchovy z roku 2002 (viz výše) a někteří dokonce před rokem 1989. V té době byla podoba ústavní výchovy od dnešní výrazně odlišná. Vzhledem k ideologickému a politickému zaměření byla ústavní výchova v dané době spíše podporována a měla podobu velkých kolektivních zařízení.

Ačkoliv se systém náhradní péče z hlediska své struktury, podílu jednotlivých typů péče a celkového diskursu v uplynulých dvou dekádách silně proměnil, výše popsané formy ústavní výchovy nadále existují a pravděpodobně i existovat budou. Je proto důležité zabývat se tím, jak se vyvíjejí děti žijící v náhradních formách péče a jak se jim daří zapojovat do dospělého života. ${ }^{5}$ Takové studie poskytují údaje využitelné v odborně-politických rozhodnutích, zda posílit určitý typ náhradní péče (např. zda rozšiřovat pěstounskou péči na úkor ústavní péče), ale také zda a jak změnit podmínky v jednotlivých typech náhradní péče tak, aby umožňovaly co nejlepší osobnostní rozvoj umístěných dětí (např. jaký je optimální poměr dětí a vychovatelů v ústavní výchově, jak připravovat pěstouny, jak s dětmi v náhradní péči hovořit o původní rodině, jak podporovat školní přípravu atd.).

V uplynulých letech 1 . lékařská fakulta Univerzity Karlovy v Praze realizovala longitudinální výzkum vlivu různých forem péče na psychický, kognitivní a sociální rozvoj dětí, v němž bylo podrobeno rozsáhlé baterii psychologických testů 190 dětí z ústavní výchovy, z náhradní rodinné péče a z původních

5 Českou tradici takto zaměřených výzkumů založil tým Z. Matějčka a J. Langmaiera. Od jejich původních studií však došlo $\mathrm{k}$ mnoha změnám $\mathrm{v}$ systému péče i obecně ve společnosti, a proto je na místě ověřit platnost jejich závěrů v současné době, respektive identifikovat nové trendy a aspekty $\mathrm{v}$ dané problematice. 
rodin (Ptáček et al., 2011, 2014). Součástí výzkumu byla také jednorázová paralelní studie zaměřená na dospělé osoby prošlé náhradními formami péče. Tuto studii realizoval v roce 2013 tým katedry psychologie Pedagogické fakulty Univerzity Karlovy v Praze. Studie sledovala charakteristiky dvou skupin osob starších 18 let, z nichž jedna strávila v průběhu svého dětství alespoň šest let $\mathrm{v}$ náhradních formách péče, zatímco druhá žila ve své původní rodině. Uvedené skupiny byly srovnávány z hlediska osobnostních charakteristik, depresivity a neuroticismu, copingových strategií, životní spokojenosti, hodnotové orientace, množství a kvality vztahů atd.

Studie zjistila, že ve skupině osob prošlých náhradními formami péče existuje signifikantně nižšś životní úroveň, vyšší nezaměstnanost a převaha méně kvalifikovaných zaměstnání než ve skupině osob vyrůstajících ve svých původních rodinách. Protože dosažené vzdělání ovlivňuje pracovní kariéru (Burda et al., 2003) a úspěch ve vzdělání je u osob z institucionální výchovy považován za jeden $\mathrm{z}$ rozhodujících faktorů k dalšímu úspěchu (Jackson \& Martin, 1998), byla ve studii věnována výzkumná pozornost také postojům ke vzdělávání, průběhu vzdělávací dráhy a doplňkovým faktorům. $\mathrm{V}$ tomto článku prezentujeme hlavní zjištění týkající se školní docházky osob, které vyrůstaly v náhradních formách péče a v původních rodinách, a zasazujeme je do kontextu jejich osobnostních i dalších charakteristik.

\section{Cíle výzkumu a výzkumné otázky}

Jak bylo uvedeno, výzkum si kladl za cíl zmapovat charakteristiky dospělých osob, které v průběhu svého dětství měly zkušenost s náhradními formami péče, a porovnat je s osobami bez této zkušenosti. Výzkum probíhal ve dvou fázích - první byla založena na rozsáhlém písemném sběru dat, druhá na hloubkovém individuálním rozhovoru s vybranými respondenty. Výzkum byl zaměřen na zodpovězení následujících základních otázek:

1. Jaké jsou psychické charakteristiky osob, které v dětství prošly náhradními formami péče ( $\mathrm{v}$ porovnání $\mathrm{s}$ osobami bez této zkušenosti)?

2. Jaký typ interpersonálních vztahů navazují osoby, které v dětství prošly náhradními formami péče (v porovnání s osobami bez této zkušenosti)?

3. Jaký životní styl, včetně vzdělávací a pracovní dráhy mají osoby, které $\mathrm{v}$ dětství prošly náhradními formami péče ( $\mathrm{v}$ porovnání $\mathrm{s}$ osobami bez této zkušenosti)? 
4. Jaký subjektivní význam spojují osoby, které v dětství prošly náhradními formami péče, $s$ tímto typem životní zkušenosti (v porovnání s osobami vyrůstajícími v původní rodině)?

Prostřednictvím několika metod bylo shromážděno velké množství dat, které jsme podrobili jak souhrnné analýze, tak dílčím tematickým analýzám. Jako jedna z klíčových oblastí se ukázala vzdělávací trajektorie, která korelovala jak s pracovním uplatněním a životní úrovní, tak s životní spokojeností, depresivitou a copingovými strategiemi. Zkušenosti spojené se školou se tedy ukázaly jako zásadní pro vývoj života v dospělosti. Proto jsme provedli samostatnou analýzu, jejímž cílem bylo sledovat rozdíly ve vzdělávací trajektorii u dospělých, kteří prošli $v$ průběhu dětství náhradní formou péče, a to v porovnání s dospělými, kteří vyrůstali ve svých původních rodinách.

\subsection{Výzkumný soubor}

Výzkumnou skupinu tvořilo 128 dospělých osob, které strávily v průběhu dětství nejméně šest let $\mathrm{v}$ náhradních formách péče. Zkušenosti $\mathrm{s}$ různými typy péče se $\mathrm{v}$ jednotlivých prŕpadech kombinují. Většina respondentů $\mathrm{z}$ výzkumné skupiny žila určitou dobu ve své původní rodině, odkud přecházeli do náhradní péče, př́ípadně byli do náhradní péče zařazeni ihned po narození.

Výzkumná skupina byla oslovena několika způsoby: prostřednictvím dětských domovů, které informaci o výzkumu zprostředkovaly svým bývalým klientům (jsou-li s nimi v kontaktu), prostřednictvím neziskových organizací zaměřujících se na pomoc lidem opouštějícím ústavní výchovu, prostřednictvím sociálních kurátorů pro dospělé a dále prostřednictvím inzerátů na internetu a $\mathrm{v}$ denním tisku. Kontrolní skupina byla převážně sestavena z osob, které si (při splnění zařazujících podmínek) přivedli lidé z výzkumné skupiny. Důvodem pro toto opatření byla snaha sestavit obě skupiny z osob z podobného prostředí, které se liší primárně v typu péče v dětství. ${ }^{6}$

6 Od způsobu výběru kontrolní skupiny podle výzkumné jsme očekávali rozdíl skupin zejména ve sledované oblasti, ačkoli si dobře uvědomujeme riziko falešné normality kontrolní skupiny. Rodinné zázemí v kontrolní skupině vykazovalo řadu problematických jevů, které by mohly naznačovat méně kvalitní výchovnou péči, např. vysoký podíl rozvodovosti či alkoholismus otců. Na rozdíl od výzkumné skupiny ale měla výchovná péče individuální charakter a byla vázána alespoň na jednu konstantní osobu. Z vývojově-psychologického hlediska jsou právě tyto dva parametry péče klíčové. Vzhledem $\mathrm{k}$ záměru sledovat zejména odlišný typ výchovy a péče (náhradní/vlastní) nebyla stanovena konkrétní kritéria pro výběr respondentů, jako je vzdělanostní úroveň rodičů nebo socioekonomický statut rodiny, ani charakter náhradní péče či vzdělání vychovatelů. Na základě zkušeností z terénu jsme přesvědčeni, že by podobná kritéria nebylo možné naplnit. Podrobné údaje z dotazníku nám nicméně dovolují provádět následné analýzy při zohlednění některých z nich. Přesto jsme si vědomi limitů v rámci designu výzkumu a možného vlivu těchto proměnných na výsledky studie. 
Pro doplnění kontrolní skupiny byly použity inzeráty. Sběr dat probíhal během šesti měsíců roku 2013, a to v devíti městech po celé ČR.

Tabulka 2

Frekvence forem péče ve výzkumné skupině

\begin{tabular}{lcc}
\hline & Počet respondentů & Podíl \\
\hline Původní rodina & 89 & $75 \%$ \\
Adoptivní rodina & 11 & $9 \%$ \\
Pěstounská rodina & 34 & $29 \%$ \\
Ústavní výchova & 102 & $86 \%$ \\
\hline
\end{tabular}

Pozn. Tabulka udává počet respondentů s alespoň 2letým pobytem v daném typu péče.

Ve výzkumné skupině bylo 64 mužů a 64 žen (podrobnosti viz tabulka 2). Jejich průměrný věk byl 26 let (minimum 18, maximum 57 let). Kontrolní skupinou bylo 103 dospělých osob, které vyrůstaly ve svých původních rodinách. $Z$ toho bylo 49 žen a 54 mužů. Jejich průměrný věk činil 28 let (minimum 18, maximum 59 let). Vzhledem k tomu, že systém náhradní péče prodělal v uplynulých 20 letech řadu změn (např. přechod na rodinné skupiny $\mathrm{v}$ dětských domovech a podpora pěstounské péče), porovnávali jsme dvě skupiny respondentů odlišného věku. Jako hranice bylo zvoleno rozmezí 24 a 25 let, které odděluje osoby narozené před a po roce 1989, které měly rozdílnou možnost setkat se s odlišnými podmínkami náhradní péče. Ve výzkumné skupině tvořily osoby rovny nebo mladší 24 let $54 \%$, v kontrolní skupině $57 \%$.

Již byla krátce zmíněna normalita $v$ kontextu výběru kontrolní skupiny, je třeba ale reflektovat také to, že závažné vybočení z normy může mít za následek umístění dítěte mimo rodinu nebo vážné dopady na jeho vývoj. Proto věnujeme otázce normality rodin ještě pár slov. Normy, od nichž je odvozeno pojetí toho, co je normální, mají tři základní podoby - může se jednat o normy statistické, normy kulturní či tradiční a normy individuální. Statistická norma považuje za normální to, co je nejrozšířenější. V souvislosti s uvedenou studií je nutné tento pohled uvést do souvislosti minimálně se sociální stratifikací, kdy pro každou sociální skupinu může být norma statistická i kulturní někde jinde. Např. Foucault (1994) ukazuje různou normu společnosti skrze proměny př́stupu k psychickým nemocem (a potažmo také k chudým) ve vymezeném geografickém i historickém ohraničení. Podpůrná 
péče se průběžně střídala s represí, přístup byl závislý na ekonomické situaci. Různý pohled na vymezenou skupinu dokládá různý pohled na normu. Ačkoli se ve studii přikláníme ke statistickému pojetí normy, z výše uvedených pohledů na normalitu vyplývá, že samotná odborná představa o normě rodiny je fakticky také určitým dobovým konstruktem a záleží, z jakého pohledu se na ni nahlíží.

\subsection{Metody sběru dat}

Výzkum využíval smíšenou kvantitativně-kvalitativní metodologii a byl realizován v rámci korelačního designu, který zjištuje souvislost mezi různými znaky. Jako metody sběru dat byly použity: (a) rozsáhlý anamnestický dotazník, (b) baterie 13 psychologických testů, (c) polostrukturované rozhovory s 20 vybranými respondenty z výzkumné skupiny. Do dílčí analýzy vzdělávacích trajektorií byly využity jen některé zdroje, ty představíme podrobněji.

Anamnestický dotazník zahrnoval 34, resp. 38 položek (jednotlivých otázek či baterií). Dotazník sledoval zejména následující oblasti - životní hodnoty a spokojenost ve vzdělávací, pracovní a vztahové oblasti, informace o rodičích a náhradních formách péče, hodnocení kvality jednotlivých prostředí, průběh školní docházky, vztahy se spolužáky, zdravotní stav, zneužívání návykových látek atd.

NEO, Pětifaktorový osobnostní inventář, představuje vícedimenzionální test, který slouží k identifikaci pěti obecných, široce pojatých dimenzí osobnosti, kterými jsou dimenze neuroticismus, extraverze, otevřenost vůči zkušenosti, př́větivost a svědomitost. Prostřednictvím daných oblastí se sleduje např. náchylnost k psychickému vyčerpání, kvalita a kvantita interpersonálních interakcí, motivace a vytrvalost na cíl zaměřeného chování atd. Ve výzkumu byla použita česká revidovaná verze, a to v sebeposuzovací variantě (Hřebíčková, 2004).

PSSI (Inventár stylů osobnosti a poruch osobnosti) je sebeposuzovací metoda zaměřená na vyhraněnost osobnostních profilů. Slouží zejména pro identifikaci individuálního stylu, který je typický pro určitého jedince, nebo k identifikaci stylů, v jejichž rámci se určitý jedinec může profilovat. Zachycené styly se odlišují charakteristickými emočními dispozicemi a upřednostňovanými formami kognitivního zpracování. Ve výzkumu byla použita česká verze testu od Švancary (2002). 
Dotazník SVF 78 je vícedimenzionální sebepozorovací inventář, který zachycuje variabilitu způsobů, jež jedinec rozvíjí a uplatňuje při zpracování a zvládání zátěžových situací. Jeho prostřednictvím se zjišt’uje, které ze 14 copingových strategií jsou pro daného člověka typické. Ve výzkumu byla použita česká verze zpracovaná Švancarou (2003).

Do následné druhé fáze, tedy $\mathrm{k}$ hloubkovým rozhovorům, bylo vybráno 10 respondentů a 10 respondentek z výzkumné skupiny. Jednalo se o zástupce dvou základních typů osob - ti, kteří byli spokojeni a měli dobré životní uplatnění, a ti, kteří byli méně spokojeni a měli horší životní uplatnění. Dále bylo také přihlíženo, zda respondent/ka má nebo nemá zkušenost s pěstounskou péčí. Všechny rozhovory byly analyzovány za pomocí kvalitativních postupů, zejména narativní a diskurzivní analýzy. Studie je informacemi z těchto analýz doplněna, i když primárně využívá kvantitativně zpracovaná data z dotazníku a psychologických testů.

Protože anamnestický dotazník i psychologické testy byly použity ve výzkumné i kontrolní skupině ve stejném znění, bylo možné provádět kompletní porovnání, a to pomocí chí-kvadrátu a t-testu. Dále byly používány korelační analýza a faktorová analýza. Signifikantní významnost byla sledována na hladině významnosti 0,05.

Při zpracování dat jsme rozdělili výzkumnou skupinu ještě na podskupiny podle kombinace forem péče, $s$ níž se v průběhu svého života (od narození do 18 let) respondenti setkali. Ačkoli v tomto článku nejde o porovnání mezi jednotlivými podskupinami, tam, kde jsou rozdíly, data uvádíme (např. viz obr. 2).

\section{Výzkumné výsledky}

\subsection{Dosažené vzdělání a cesty k němu}

Struktura nejvyššího dosaženého vzdělání ve výzkumné a kontrolní skupině se statisticky významně liší, a to $v$ neprospěch výzkumné skupiny, $\chi^{2}(11$, $n=231)=48,8, p<0,01$. V průměru kontrolní skupina dosáhla vyššího vzdělání (nejčastěji odborného vzdělání s maturitou), zatímco ve výzkumné skupině odpovídá průměrná hodnota dosaženého vzdělání učebnímu oboru bez výučního listu (modus skupiny odpovídá učebnímu oboru s výučním listem). 
Ve výzkumné skupině je relativně velký počet respondentů (30\%), kteří dosáhli pouze základního vzdělání, přičemž signifikantně častěji se jednalo o základní školu praktickou, respektive zvláštní. Významný rozdíl se týká také podílu absolventů gymnázií (1\% ku $10 \%)$ a oborů s maturitou, který následně ovlivňuje podíl osob s vysokoškolským vzděláním (4\% ku $11 \%)^{7}$. Zatímco ve výzkumné skupině skončilo $78 \%$ osob se vzděláním bez maturity, v kontrolní skupině se jedná pouze o $38 \%$ (viz obr. 1).

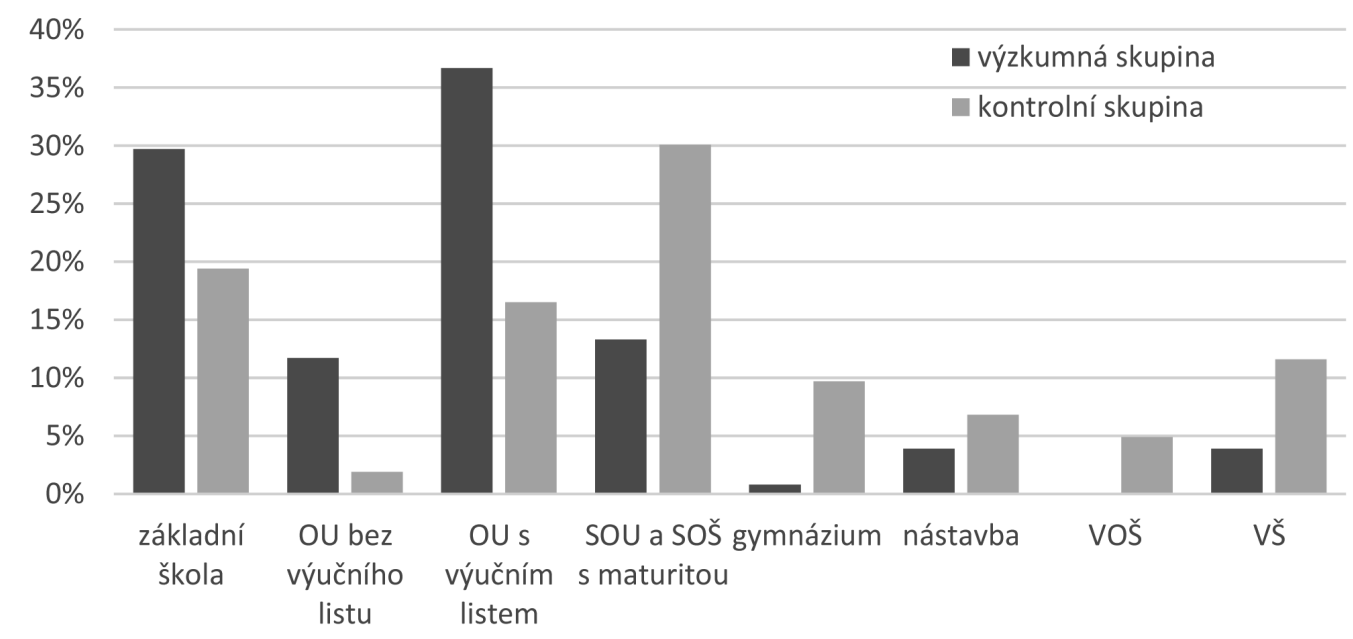

Obrázek 1. Graf rozložení dosaženého vzdělání u výzkumné a kontrolní skupiny.

Při porovnávání mladší a starší kategorie respondentů (tj. s hranicí 24-25 let) se sice ve výzkumné i kontrolní skupině ukázala nižší úroveň dosaženého vzdělání u starších respondentů, nicméně tento rozdíl nebyl statisticky významný. $\mathrm{V}$ př́ípadě obou věkových kategorií se ale výzkumná a kontrolní skupina výrazně lišily, a to v neprospěch osob vyrůstajících mimo původní rodinu. Při bližším pohledu do mladší kategorie (tj. osoby 24leté a mladší) dosáhlo pouze základního vzdělání $24 \%$ osob v kontrolní skupině a $33 \%$

\footnotetext{
Nicméně je třeba zdůraznit, že $32 \%$ respondentů z kontrolní skupiny a $22 \%$ z výzkumné skupiny ještě $v$ době sběru dat pokračovala ve studiu, a to nejčastěji na nástavbě či vysoké škole. Vzdělanostní struktura v dospělé populaci obou skupin po ukončení studia se tedy ještě může mírně změnit, avšak nepředpokládáme, že by mohlo zcela dojít ke zvrácení celkově vyšší úrovně dosaženého vzdělání v kontrolní skupině. Jak naznačuje rozbor výsledků po vyjmutí dosud studujících respondentů, konečná struktura vzdělanosti bude pravděpodobně kopírovat stávající rozložení.
} 
ve výzkumné skupině. Vysokou školu vystudovalo či ještě studuje $17 \%$ kontrolní skupiny, ale jen 3 \% výzkumné skupiny.

Obě skupiny se liší i v preferovaných studijních oborech. Ve výzkumné skupině dominují obory spojené s pohostinstvím, tj. kuchař/ka či číšník/servírka, které studovalo $26 \%$, zatímco v kontrolní skupině si tento obor zvolilo pouze $5 \%$. Druhou nejrozšsiřrenější oblast představují řemeslné obory (např. truhlářství), které absolvovalo $14 \% \mathrm{z}$ výzkumné skupiny, ale jen $6 \%$ z kontrolní skupiny. Naopak v kontrolní skupině byly nejčetněji studovanými obory správní a provozní, které zvolilo $25 \%$, ale jen $12 \%$ z výzkumné skupiny, a dále technické obory, jako je strojírenství či IT, které absolvovalo $22 \%$ z kontrolní, ale jen $6 \%$ z výzkumné skupiny.

Respondenti byli v dotazníku požádáni o zhodnocení spokojenosti s úrovní svého vzdělání, a to výběrem ze čtyř odpovědí, které uvádí tabulka 3. Polovina respondentů ve výzkumné skupině je se svým vzděláním spokojená. Zároveň však je ve výzkumné skupině jednak rozšířenější nezájem o vzdělání, jednak dojem omezených možností při vzdělávání. Tento rozdíl se nicméně neukázal statisticky významný, $\chi^{2}(3, n=218)=3,43, p=0,182$. Můžeme tedy shrnout, že ačkoliv obě skupiny dosahují rozdílného vzdělání, hodnotí jej obdobně a dosahují i obdobné spokojenosti.

Tabulka 3

Subjektivní hodnocení vzdělávací dráhy

\begin{tabular}{lcc}
\hline & Výzkumná skupina & Kontrolní skupina \\
\hline Dosáhl/a jsem vzdělání, které jsem chtěl/a. & $50,8 \%$ & $57,4 \%$ \\
Mám vyšší vzdělání, než jsem původně chtěl/a. & $1,6 \%$ & $4,3 \%$ \\
Chtěl/a jsem ve studiu pokračovat, ale nebylo to & $39,5 \%$ & $34,0 \%$ \\
možné. & & $4,3 \%$ \\
O vzdělání jsem nikdy neměl/a zájem. & $8,1 \%$ & \\
\hline
\end{tabular}

Postoje ke vzdělání se utváří v průběhu života pod vlivem okolí a vlastních zkušeností. Následně pak tyto postoje ovlivňují další studijní motivaci a výkony (Burda et al., 2003). Může tak docházet k jistému zacyklení, kdy určitý typ postoje je prohlubován reálnými neúspěchy, které z tohoto postoje vyplývají. V této souvislosti jsme $\mathrm{v}$ dotazníku sledovali, jaký byl průběh školní kariéry v dětství. Vybrané parametry prezentuje tabulka 4. 
Tabulka 4

Průběh školního vzdělávání - vybrané charakteristiky

\begin{tabular}{lcc}
\hline & Výzkumná skupina & Kontrolní skupina \\
\hline Docházka do mateřské školy & $79,7 \%$ & $83,5 \%$ \\
Opakování ročníku v průběhu ZŠ & $23,4 \%$ & $12,6 \%$ \\
Snížená známka z chování & $42,2 \%$ & $30,1 \%$ \\
\hline
\end{tabular}

Pozn. Tabulka zobrazuje souhlasné odpovědi.

Z hlediska docházky do mateřské školy se výzkumná a kontrolní skupina neliší. Před vstupem do školní instituce ale někteří respondenti navštěvovali ještě také jesle. ${ }^{8}$ Osoby z výzkumné skupiny oproti kontrolní skupině je navštěvovaly signifikantně častěji $(\mathrm{p}<0,05)$. Ačkoliv lidé narození po roce 1989 docházeli do jeslí výrazně méně než starší lidé, byl jejich podíl ve výzkumné skupině výrazně větší ( $5 \%$ kontrolní skupiny vs. $15 \%$ výzkumné skupiny). Vysoký podíl docházky do jeslí existuje i v případě osob z výzkumné skupiny, které do tří let žily $\mathrm{v}$ původní rodině. Nemusí se však jednat výhradně o důsledek slabších vztahově-emočních charakteristik výchovy v rodinách, z nichž následně byly děti umístěny do náhradních forem péče, nýbrž příčinou vyšší docházky do jeslí mohla být nižší životní úroveň v těchto rodinách, kvůli čemuž oba rodiče museli odcházet do zaměstnání (př́ípadně jeden rodič, který se o dítě staral sám).

Významné rozdíly ve sledovaných skupinách nacházíme také při zaměření na období docházky do základní školy. Ve výzkumné skupině existuje signifikantně vyšší výskyt opakování ročníku i zhoršených známek z chování $(\mathrm{p}<0,05)$. Oba výsledky korespondují s intenzivnějšími problémy při zvládání školních povinností. Školní kariéra byla ve výzkumné skupině komplikovanější i z hlediska počtu základních škol, na kterých respondenti plnili svoji povinnou docházku. Více než dvě základní školy navštěvovalo $11 \%$ osob z kontrolní skupiny, ale $47 \%$ z výzkumné skupiny. Průměrný počet navštěvovaných základních škol byl v kontrolní skupině 1,5, zatímco ve výzkumné skupině 2,3 . Tento rozdíl pochopitelně souvisí s přesunem z původní rodiny do náhradních forem péče, který obvykle zahrnuje také změnu

8 Jak ukazuje řada zahraničních výzkumů, docházka do společných zařízení před třetím rokem věku nemá na vývoj dětí nezbytně negativní vliv. Naopak výzkumy naznačují, že zejména u dětí ze sociálně znevýhodněných skupin může docházka do jeslí i zvyšovat jejich následnou školní úspěšnost (Hašková, Saxonberg, \& Mudrák, 2012). 
základní školy. V každém případě však přesuny představují zátěž z hlediska školní úspěšnosti, nebot' adaptace na novou vrstevnickou skupinu, učitele i způsob práce, je pro většinu dětí obtížnější (zvláště v tíživé životní situaci ztráty původní rodiny). Obtížná adaptace může vést ke zhoršeným známkám z chování i k opakování ročníku. Ty se však výrazně častěji ve výzkumné skupině objevovaly i u dětí, které neprodělaly v průběhu základní školy přechod z původní rodiny do náhradních forem péče, tj. u dětí, které již žily mimo původní rodinu v předškolním období.

V obou skupinách se prokázal rozdíl i s ohledem na věk. V mladší kategorii (tj. lidé 24letí a mladší) bylo opakování ročníku zastoupeno ve $14 \%$ u kontrolní skupiny a v $25 \%$ u výzkumné skupiny. Obdobný rozdíl se vyskytoval i ve starší kategorii. Zhoršená známka $\mathrm{z}$ chování byla rovněž $\mathrm{v}$ obou věkových kategoriích signifikantně více zastoupena u výzkumné skupiny, přičemž podíl zhoršených známek je $\mathrm{v}$ uplynulých 20 letech vyšší než v minulosti. Zatímco u starších lidí odpovídalo, že zhoršenou známku z chování dostalo $27 \%$ kontrolní skupiny a $36 \%$ výzkumné skupiny, u mladší kategorie to bylo $32 \%$ a $48 \%$.

Tabulka 5

Zvládání školních povinností

\begin{tabular}{lcc}
\hline & Výzkumná skupina & Kontrolní skupina \\
\hline Výborně a dobře & $62,5 \%$ & $80,5 \%$ \\
S obtížemi a špatně & $29,7 \%$ & $15,5 \%$ \\
Neví & $7,8 \%$ & $3,9 \%$ \\
\hline
\end{tabular}

V tabulce 5 je opět patrné, že osoby z výzkumné skupiny častěji reflektovaly své problémy se zvládáním školních povinností. Údaje za obě skupiny jsou statisticky významně rozdílné, $\chi^{2}(4, \mathrm{n}=222)=13,5, \mathrm{p}<0,05$. Hodnocení vlastního zvládání školních úkolů vykazovalo v obou skupinách v mladší kategorii lepší úroveň a rozdíl oproti starším respondentům byl statisticky významný. Zatímco mladší lidé posuzovali své zvládání školy jako výborné v $37 \%$ v kontrolní skupině a $20 \%$ ve výzkumné skupině, mezi staršími respondenty byla tato odpověd' zvolena v $25 \%$ v kontrolní skupině a $10 \%$ ve výzkumné skupině.

Obtíže při zvládání školních povinností mohou souviset také se způsobem školní př́ipravy. Z rozhovorů vyplynulo, že osoby se zkušeností s ústavní výchovou měly horší podporu při školní přípravě. Příprava do školy probíhala 
téměř vždy hromadně, a to nejčastěji ihned po příchodu z výuky a zpravidla byla silně založena na samostatnosti dětí. Vychovatelka byla připravena jim pomoci, pokud o to požádají (případně pokud hrozí ve škole selhání, které lze na základě minulých výsledků předpokládat). Většina respondentů v rozhovoru ale zmiňovala, že jim šlo primárně o to, mít čas př́ípravy na školu co nejkratší, a proto se jen zřídka snažili využít nabídku pomoci od vychovatelky. Připomínáme, že iniciativa musela vyjít od nich, což představuje velký rozdíl oproti domácí př́ípravě v původních rodinách. Ve škole se dále potkávali s různými úlevami ze strany vyučujících, které však v dlouhodobém horizontu přináší znevýhodnění.

Z prezentovaných výsledků lze usuzovat, že na nižší vzdělanostní úrovni osob vyrůstajících $\mathrm{v}$ náhradních formách péče se podílí méně funkční př́íprava na školu v dětských domovech a náhradních rodinách. Ačkoli podobné závěry ukazuje i zahraniční studie (Martin \& Jackson, 2002), taková interpretace by $\mathrm{v}$ našem př́padě byla unáhlená. Pro úplnost v tabulce 6 uvádíme nejvyšší dosažené vzdělání rodičů respondentů z výzkumné a kontrolní skupiny, které se statisticky významně liší. $V$ případě výzkumné skupiny dosáhli rodiče respondentů signifikantně nižšího vzdělání, přičemž vzdělání matek bylo nižší než vzdělání otců. ${ }^{9}$ Se slabší vzdělanostní úrovní souvisí horší uplatnění na trhu práce a pravděpodobně i nižší životní úroveň, které mohly být důvodem pro odebrání dětí z původní rodiny. ${ }^{10}$

Pokud srovnáme vzdělanostní strukturu respondentů a jejich rodičů, bylo prokázáno její zvýšení. Např́iklad ve výzkumné skupině je aktuálně podíl osob s maturitou $15 \%$, ale v generaci rodičů pouze $7 \%$, podíl osob s vysokou školou 3,9\%, ale v generaci rodičů pouze 1,2\% (v kontrolní skupině došlo v mezigeneračním intervalu ke zdvojnásobení podílu maturity, ale k žádnému posunu v podílu vysoké školy).

9 Tyto informace byly zprostředkované respondenty a je třeba mít na paměti, že respondenti, kteří prošli náhradními formami péče, nemají vždy o svých rodičích přesné údaje.

10 Špatnou finanční a materiální situaci uvádělo jako důvod opuštění původní rodiny 19,2 \% osob z výzkumné skupiny. Dalším nejčastějším důvodem byla špatná rodičovská péče $(22,9 \%)$. 
Tabulka 6

Dosažené vzdělání rodičů respondentů

\begin{tabular}{llcc}
\hline & & Výzkumná skupina (\%) & Kontrolní skupina (\%) \\
\hline \multirow{2}{*}{ Matka } & Základní škola & 43,0 & 15,3 \\
& Učební obor s výučním listem & 16,3 & 30,6 \\
& SOU a SOŠ s maturitou & 5,9 & 13,3 \\
& Nástavba, vyšší odborná škola & 33,7 & 28,6 \\
& Vysoká škola & 1,2 & 12,2 \\
\hline \multirow{2}{*}{ tetec } & Základní škola & 26,6 & 12,8 \\
& Učební obor s výučním listem & 20,3 & 17,0 \\
& SOU a SOŠ s maturitou & 8,9 & 16,0 \\
& Nástavba, vyšší odborná škola & 43,0 & 44,7 \\
& Vysoká škola & 1,3 & 9,6 \\
\hline
\end{tabular}

Můžeme tedy shrnout, že osoby vyrůstající mimo původní rodinu sice dosahují oproti kontrolní skupině nižší absolutní úrovně dosaženého vzdělání, ale v mezigenerační relaci se jejich vzdělanostní úroveň zvyšuje v obdobné míře. $\mathrm{V}$ rozhovorech několik respondentů explicitně zdůrazňovalo, že život v náhradní péči jim umožnil vymanit se ze špatných sociálně-ekonomických podmínek a nízké úrovně vzdělání. Pro ilustraci uvádíme výrok 22letého muže, který při hodnocení osmi let strávených v dětském domově spontánně porovnával svůj život s životem jeho sourozenců, kteří zůstali v původní rodině: „Mám školu a pracuju. Kdybych zůstal doma, tak bych asi ani neudělal základku."

\subsection{Vzdělání a osobnostní charakteristiky}

V analýze se ukázal jako významný vztah mezi vzděláním a některými osobnostními charakteristikami sledovanými psychologickými testy. Nejvyšší korelace existuje mezi vzdělávací trajektorií a osobnostními styly a strategiemi, které prezentuje tabulka 7 . V uvedených položkách byly zjištěny zároveň signifikantní rozdíly mezi výzkumnou a kontrolní skupinou.

Při porovnání kontrolní a výzkumné skupiny v jednotlivých pěti škálách dotazníku NEO se statisticky významný rozdíl prokázal pouze na škále neuroticismu ${ }^{11}$, a to i v př́padě zohledňování věkových kategorií. Podskupiny

11 Dimenzí neuroticismus není myšlena psychiatrická kategorie, ale sledujeme skrze ni individuální rozdíly v oblasti emocionální stability (resp. nestability). Vysokého skóru dosahují 
výzkumné skupiny nevykazovaly statisticky významné rozdíly, nicméně ve skupině bez zkušenosti s rodinnou výchovou byl v této škále vyšší průměr o 3 body. Ve vztahu ke vzdělávací trajektorii byl prokázán významný vztah mezi výší dosaženého vzdělání a mírou neuroticismu u kontrolní skupiny. Jedno z možných vysvětlení je, že mechanismus, kterým neuroticismus ovlivňuje vzdělávání, funguje u obou skupin odlišně, nebo že je shodný, avšak u výzkumné skupiny, která dosahovala celkově nižšího vzdělání, neměl možnost se tak silně projevit.

Tabulka 7

Vybrané osobnostní charakteristiky s vazbou na nejvyšší dosažené vzdělávání

\begin{tabular}{lcccccc}
\hline & \multicolumn{3}{c}{ Výzkumná skupina } & \multicolumn{3}{c}{ Kontrolní skupina } \\
\cline { 2 - 7 } & $\begin{array}{c}\text { Průměrný } \\
\text { hrubý skór }\end{array}$ & SD & P. C. & $\begin{array}{c}\text { Průměrný } \\
\text { hrubý skór }\end{array}$ & SD & P. C. \\
\cline { 2 - 7 } NEO - Neuroticismus & 25,7 & 8,2 & $-0,08$ & 22,1 & 5,9 & $0,31^{* *}$ \\
PSSI - Intuitivní styl & 16,2 & 4,9 & $-0,17$ & 13,7 & 4,7 & $-0,34^{* *}$ \\
PSSI - Sebenejistý styl & 15,3 & 5,9 & $-0,09$ & 12,0 & 5,6 & $-0,35^{* *}$ \\
PSSI - Nedůvěrivý styl & 13,8 & 4,1 & $-0,14$ & 11,9 & 4,2 & $-0,26^{* *}$ \\
SVF 78 - Kontrola situace & 14,8 & 4,9 & $0,24^{* *}$ & 16,5 & 3,8 & 0,19 \\
SVF 78 - Rezignace & 11,6 & 4,7 & $-0,02$ & 9,6 & 4,3 & $-0,34^{* *}$ \\
SVF 78 - Sebeobviňování & 12,8 & 5,2 & $-0,04$ & 11,4 & 4,8 & $0,23^{*}$ \\
\hline
\end{tabular}

Pozn. P. C., Pearson Correlation, vztah mezi danou položkou a výší dosaženého vzdělání; ${ }^{* *} \mathrm{p}<0,01 ; * \mathrm{p}<0,05$.

Z výsledků testu PSSI vyplývá, že lidé vyrůstající v náhradních formách péče, mají větší problémy s rozlišováním hranic mezi sebou a druhými. Potíže s detekcí hranic se mohou projevovat více způsoby, např. neadekvátním připisováním odpovědnosti či viny (sobě, druhým, případně oboje v závislosti na situaci). Dále test ukazuje, že osoby z výzkumné skupiny jednají více impulzivně, což může být reakce na vnitřní úzkost nebo naučená strategie k získávání pozornosti druhých, a dále mají silnější sklony ke zpochybňování sebe sama. Sebenejistota a nedůvěřivost souvisí s nižším sebepojetím, které u klientů institucionální výchovy dokládá řada studií (např. Kellerhals, 1992; Matějček, 1994; Ptáček et al., 2011). Můžeme odvozovat, že malé sebepojetí

ti jedinci, kteř́i jsou často nejistí až úzkostní, intenzivně prožívají obavy, případně smutek. Naopak emocionálně stabilní jedinci, projevující se jako klidní, vyrovnaní, dosahují nízkého skóru (Hřebíčková, 2004). 
může být důsledkem nízkého dosaženého vzdělání (respektive sociálního statutu), ale rovněž může být jedním ze zdrojů nižší školní úspěšnosti, nebot' vede k rezignaci při řešení náročných úkolů. $V$ př́ípadě kontrolní skupiny souvisí sebejistota s dosaženým vzděláváním - jedinci s nižšśm dosaženým vzděláním se projevovali více sebenejistě a nedůvěřivě. Signifikantní rozdíl mezi skupinami a zároveň vztah k dosaženému vzdělání (v kontrolní skupině) byl prokázán také u intuitivního stylu, který se vyznačuje vyšší mírou senzitivity, takoví lidé mají tendenci reagovat úzkostněji. Výzkumná skupina vykazovala výrazně vyšší míru intuitivního stylu, ale přitom nebyl prokázán vztah mezi ním a dosaženým vzděláním (suspektně opět vzhledem k celkově nižšímu vzdělání). Mezi podskupinami výzkumné skupiny byl v uvedených škálách rozdíl na škále zobrazující intuitivní a sebenejistý styl (viz obr. 2).

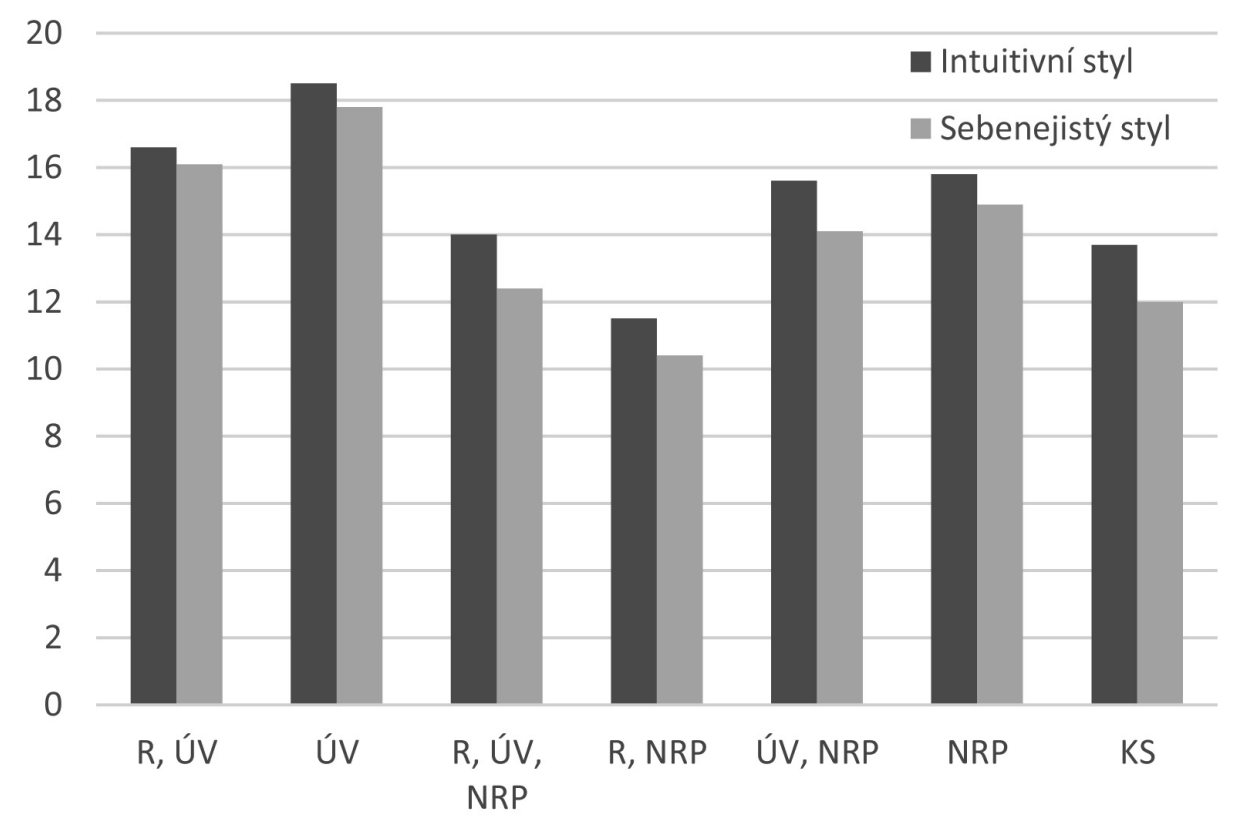

Obrázek 2. Graf rozložení průměrných hodnot vybraných škál mezi podskupinami výzkumné skupiny. Označené sloupce udávají kombinace typů péče, kterými respondenti z dané skupiny prošli: R - rodinná výchova, ÚV - ústavní výchova, NRP - náhradní rodinná péče (pěstounská a adoptivní), KS - kontrolní skupina.

Dotazník SVF 78 ukázal, že lidé z výzkumné skupiny ve stresových situacích, které mohou vznikat i v průběhu školní docházky, významně častěji obviňují sami sebe. Můžeme také usuzovat na naučené reakce na stresové situace, kdy 
jsou děti vystavené zátěžovým a traumatickým situacím (jak v rodině, kde byly zneužívány či zanedbávány, tak při odebrání z rodin, které pro ně představovaly určitý typ jistoty a známé prostředí) často ze svého úhlu pohledu bezmocné. ${ }^{12}$ Nižší kontrola nad situací a tendence k rezignaci se projevovaly silněji ve výzkumné skupině jak u mladších, tak starších respondentů. Mezi podskupinami podle typů péče ve výzkumné skupině nebyl významný rozdíl. U kontrolní skupiny se projevily tendence k rezignaci, které byly tím slabší, čím bylo vyšší vzdělání respondentů, zatímco u výzkumné skupiny se tento vztah jako významný neprokázal (suspektně vlivem celkově nižšího dosaženého vzdělání). Ve vztahu ke vzdělávací trajektorii se ale u výzkumné skupiny statisticky významně projevil vztah mezi dosaženým vzděláním a tendencí ke kontrole situací. Taková reakce spočívá ve snaze řídit události, kterých jsme součástí, namísto toho podat se vnějšímu vývoji či rezignovat. Celkově platí, že snahou o kontrolu situací reagují na zátěžové události silněji osoby v kontrolní skupině, ovšem ve výzkumné skupině se jim vyrovnávají ti, kteří dosáhli vyššího vzdělání. Je tedy možné, že tato strategie stála v pozadí jejich vzdělávacího úspěchu.

Na základě uvedených dat můžeme konstatovat souvislost náhradní formy péče a nižšího vzdělání. Při interpretaci je však nezbytná velká obezřetnost, nebot' se nejedná o kauzalitu. Pro identifikaci kauzálních vztahů bychom museli brát $\mathrm{v}$ úvahu rodinnou situaci před umístěním dítěte do náhradní péče, dědičnost kognitivních schopností atd. Bez těchto údajů musíme zvažovat i takovou interpretaci, že náhradní formy péče jsou poskytovány dětem, které se od ostatní dětské populace odlišují již při vstupu do náhradní péče, a tudíž jejich další vývoj je již touto vstupní rozdílností determinován.

Jako určité omezení vnímáme samotnou formu výzkumných nástrojů, což byly písemné psychologické testy a anamnestický dotazník. Nástroje byly poměrně dlouhé, jejich vyplnění trvalo až 2,5 hodiny. To pro některé účastníky bylo náročné, a je proto možné, že jejich pozornost v průběhu testování kolísala. Znehodnocení dat jsme se ale snažili předcházet jak při samotném sběru dat, tak následným vyřazením těch testů, které vykazovaly vysokou chybovost (např. označování více odpovědí nebo jejich nevyplnění).

12 Můžeme dokonce usuzovat na existenci autoatribučního stylu naučená bezmocnost (Seligman \& Maier, 1967). 


\section{Závěr}

V uvedené studii jsme došli k závěrům, které se týkají rozdílů mezi výzkumnou a kontrolní skupinou zejména v následujících oblastech: nejvyšší dosažené vzdělání a mezigenerační posun, osobnostní charakteristiky a copingové strategie ve vztahu k dosaženému vzdělání, průběh školní docházky, spokojenost s dosaženým vzděláním, prŕíprava do školy a úlevy ve škole.

Struktura nejvyššího dosaženého vzdělání i vzdělávací trajektorie ve výzkumné a kontrolní skupině se výrazně lišila. Respondenti, kteří v dětství prošli náhradní formou péče, byli významně častěji žáky základní školy zvláštní/praktické a $\mathrm{v}$ průměru dosáhli nižšího vzdělání i jiného oborového zaměření než lidé vyrůstající v původních rodinách. Přesto ale v porovnání se vzděláním rodičů respondentů byl u výzkumné skupiny v dosaženém vzdělání větší mezigenerační posun.

Výzkumná a kontrolní skupina se liší v řadě osobnostních charakteristik, $\mathrm{z}$ nichž některé souvisí s dosaženým vzděláním. Respondenti vyrůstající mimo původní rodiny se vyznačují větší nedůvěřivostí, úzkostí, impulzivitou a sebenejistotou a v náročných situacích častěji reagují rezignací a sebeobviňováním. Tyto osobnostní rysy mohou být způsobeny narušením primární vazby s rodiči, (sub)deprivací v rámci institucionální péče a ranými traumaty. Ve všech charakteristikách byla prokázána signifikantní souvislost s úrovní vzdělání, přričemž ale nelze určit, zda byly prríčinou či důsledkem.

Jako důležitý aspekt $\mathrm{v}$ rozdílech vzdělávací trajektorie mezi sledovanými skupinami se jeví také opakování ročníku. Respondenti z výzkumné skupiny významně častěji opakovali ročník ve škole a rovněž často měnili školu, měli horší známky z chování i celkový prospěch. Navzdory odlišnému průběhu vzdělávací dráhy se její hodnocení ve výzkumné a kontrolní skupině nelišilo. Respondenti, kteří vyrůstali v náhradní péči, byli se svým vzděláním víceméně spokojeni, nicméně řada $\mathrm{z}$ nich nikdy neprojevovala o vzdělávání zájem, tudíž ani nemohla pocitovat zklamání.

Z rozhovorů se zástupci výzkumné skupiny vyplynulo, že na jejich vzdělávání může mít také vliv způsob školní přípravy, která v náhradní výchovné péči probíhala zpravidla hromadně a iniciativa bývala přenechávána dětem. Zároveň na ně byly leckdy ve škole kladeny nižší nároky a setkávali se s různými úlevami, které z dlouhodobějšího hlediska mohou mít na vzdělávací dráhu negativní dopad. 
Z uvedených poznatků vyplývají dílčí doporučení pro praxi, která mohou vést $\mathrm{k}$ tomu, aby děti z náhradních forem péče dosahovaly lepších školních výsledků. Bez ohledu na kognitivní schopnosti lze konstatovat, že úlevy ve škole a přenechávání iniciativy ve školní prrípravě dětem nejsou strategiemi, které by děti ve školní úspěšnosti podporovaly. Naopak, k progresi by mohla vést zvýšená individuální péče ve školní př́ípravě těchto dětí ze strany vychovávajících osob a adekvátní nároky ze strany pedagogů ve vzdělávacím procesu. Vzhledem k významným změnám $\mathrm{v}$ osobnostních charakteristikách osob mezi sledovanými skupinami a jejich vztahu k dosaženému vzdělání by mohl být prospěšný také nácvik zvládání zvýšené tenze, zvýšení sebejistoty a nácvik adekvátních copingových strategií dětí v náhradních formách péče, případně realizace programů primární prevence zaměřených na tuto oblast.

\section{Literatura}

Burda, V., Festová, J., Úlovcová, H., \& Vojtěch, J. (2003). Přístup mladých lidí ke vzdělávání a jejich profesní uplatnění. Praha: NÚOV. Dostupné z http://www.nuov.cz/pristup-mladych-lidi-kevzdelavani-a-jejich-profesni

Foucault, M. (1994). Dějiny šílenství. Praha: NLN s.r.o.

Hašková, H., Saxonberg, S., \& Mudrák, J. (2004). Péče o nejmenší: Boření mýtů. Praha: Slon.

Hřebíčková, M. (2004). NEO -PI-R. Praha: Testcentrum.

Jackson, S., \& Martin, P. Y. (1998). Surviving the care system: Education and resilience. Journal of Adolescence, 21(5), 569-583.

Kellerhals, J., et al. (1992). Le style éducatif des parents et l'estime de soi des adolescents. Revue française de sociologie, 33(3), 313-333.

Matějček, Z. (1994). O rodině vlastní, nevlastní a náhradní. Praha: Portál.

Martin, P. Y., \& Jackson, S. (2002). Educational success for children in public care: Advice from a group of high achievers. Child \& Family Social Work, 7(2), 121-130. Dostupné z http:// faculty.uml.edu/darcus/47.361/FOSTER\%20CARE/martin_jackson_2002_foster_ academic.pdf

Ministerstvo práce a sociálních věcí (2013). Statistická ročenka z oblasti práce a sociálních věcí 2012. Praha: MPSV. Dostupné z http://www.mpsv.cz/files/clanky/16366/rocenka_ 2012.pdf

Ministerstvo školství, mládeže a tělovýchovy (neuvedeno). Statistika dětí v institucionální výchově. Dostupné z http://www.msmt.cz/vzdelavani/socialni-programy/statistika-poctudeti-umistenych-v-zarizenich-ochranne-a

Ptáček, R., et al. (2011). Vývoj dětí v náhradních formách péče. Praha: MPSV. Dostupné z http:// www.mpsv.cz/files/clanky/13150/nahradni_pece.pdf

Ptáček, R., et al. (2014). Děti na cestě, vliv náhradních forem péče na vývoj dětí a život dospělých. Interní závěrečná zpráva. Praha: Nadace J\&T.

Seligman, M. E. P., \& Maier, S. F. (1967). Failure to escape traumatic shock. Journal of Experimental Psychology, 74(1), 1-9. 
Švancara, J. (2002). PSSI, inventář stylů osobnosti a poruch osobnosti. Praha: Testcentrum. Švancara, J. (2003). SVF, Strategie zvládání stresu SVF-78. Praha: Testcentrum.

Vocilka, M. (1999). Dětské domovy v České republice. Praha: AULA.

Zákon č. 109/2002 Sb., o výkonu ústavní výchovy nebo ochranné výchovy ve školských zařízeních a o preventivně výchovné péči ve školských zařízeních a o změně dalších zákonů, ve znění pozdějších předpisů. In Sbírka zákonů (2002). Částka 48, 2978-2992.

\section{Autoři}

Mgr. Lucie Myšková, Ph.D., Univerzita Karlova v Praze, Pedagogická fakulta, Katedra psychologie, Myslíkova 7, Praha 1, e-mail: myskoval@atlas.cz

PhDr. Irena Smetáčková, Ph.D., Univerzita Karlova v Praze, Pedagogická fakulta, Katedra psychologie, Myslíkova 7, Praha 1

Mgr. Hana Novotná, Univerzita Karlova v Praze, Pedagogická fakulta, Katedra psychologie, Myslíkova 7, Praha 1

Mgr. Jakub Onder, Univerzita Karlova v Praze, Pedagogická fakulta, Katedra psychologie, Myslíkova 7, Praha 1

RNDr. Hana Kuželová, Ph.D., Univerzita Karlova v Praze, 1. lékařská fakulta, Psychiatrická klinika, Kateřinská 32, Praha 2

PhDr. et PhDr. Radek Ptáček, Ph.D., MBA., Univerzita Karlova v Praze, 1. lékařská fakulta, Psychiatrická klinika, Kateřinská 32, Praha 2, e-mail: ptacek@neuro.cz

\section{Education of people with experience in alternative forms of care in childhood}

Abstract: The purpose of this article is to present partial results of research that examined the effect of long-term stay in alternative forms of care settings (in institutional care and in foster families) on various aspects of adult life. Monitored area in the presented study was the educational trajectory of respondents. In the first part we describe the types of these forms of care in the Czech Republic, especially institutional care. The second part presents a part of the study in which an anamnesis questionnaire and a battery of psychological tests were used in order to compare a research group of adults with an experience in alternative care $(n=128)$ and a control group of people growing up in the original families $(n=103)$. The third part of the paper is devoted to results related to educational attainment, the path to it, and also mentions perspective on educational attainment despite differences in personality traits. It turned out that people who spend the whole or part of the childhood in alternative care achieve lower forms of education, have lower educational aspirations, have larg- 
er difficulties in the school trajectory and from the surroundings receive less support of learning. From the above results follow recommendations in relation to the educational process of children placed in alternative forms of care.

Keywords: school success, education, foster care, children's home

Michek, S. (2014). Kolegiální evaluace školy. Hradec Králové: Gaudeamus.

Publikace se zabývá kolegiální evaluací školy. V první kapitole autor zmapoval, co to je kolegiální evaluace, z jakých kontextuálních východisek čerpá, kde je využívána, jak je používána ve vzdělávání, jaké jsou s ní zkušenosti nejen v zahraničí, ale i v ČR. Poté informuje o empirickém výzkumu - smíšeném výzkumném designu, který uskutečnil nejen na odborných školách v České republice. Jádro sdělení tvoří čtyři „příběhy“ případové studie kolegiální evaluace odborných škol a témata výzkumu. Případové studie popisují zákulisí plánování, realizaci a výsledky uskutečněné hodnotící návštěvy hodnotiteli. Tématy zkoumání kolegiální evaluace byly: názory a postoje ke kolegiální evaluaci, podmínky ke kolegiální evaluaci, kompetence zúčastněných, průběh kolegiální evaluace a přínosy pro školy z kolegiální evaluace a pojetí kolegiální evaluace u odborných a u základních škol. V předposlední kapitole jsou shrnuty a diskutovány výsledky výzkumu a jsou zde identifikovány a rozebírány tyto podpůrné faktory kolegiální evaluace: postoje k evaluaci, podmínky ke kolegiální evaluaci (např.časové, finanční, kapacitní, lidské zdroje, atmosféra, výběr školy), zkušenosti s evaluací, kompetence účastníků kolegiální evaluace (např. evaluační, komunikační, týmová spolupráce), interakce hodnocené školy a týmu hodnotitelů, podpora kolegiální evaluace (např. vedení školy, metodika, projekt, vnější prostředí). Na závěr jsou částečně zodpovězeny výzkumné otázky a nabídnuty perspektivy dalšího zkoumání kolegiální evaluace, tj. hodnocení týmem kolegů ze stejného prostředí, kteří mají porozumění konkrétní situaci a citlivě tak mohou napomoci při rozvoji školy. 